\title{
The beneficial effects of oral amitriptyline in anxiety- induced hyperventilation syndrome; a case series
}

\author{
Veronica A. Varney*, H Parnell and G Quirke \\ Respiratory Department, St. Helier Hospital, UK
}

\begin{abstract}
We describe 12 breathless patients all referred to respiratory outpatients where a final diagnosis of anxiety-induced chronic hyperventilation syndrome was made. Many had received treatments for asthma or COPD or cardiac disease without benefit and had attended their GP and A\&E departments repeatedly without a clear diagnosis being made; despite raised oxygen saturations and respiratory rate at rest. Referrals to rapid access chest pain clinics were also common leading to multiple other investigations with yet further patient anxiety and prolonged periods away from work.

The cases show that a clear diagnosis could have been made at the outset by a careful history particularly recognizing the circumstances at the onset of the condition, along with the presence of significant insomnia and anxiety-like symptoms with admission to panic if enquiries made.

All cases responded promptly to oral amitriptyline that was commenced at $10 \mathrm{mg}$ nocte and increased until full sleep was restored and hyperventilation ceased.

In this case series we review the topic of anxiety-induced hyperventilation and discuss data suggesting that carbon-dioxide sensitivity in the brain-stem (respiratory centre) changes during slow wave sleep. Serotonergic neurons influence this, causing respiratory depression and tricyclic drugs enhance the activity of these neurons and are described to alleviate symptomatic hyperventilation by restoring slow wave sleep. This would be a reasonable treatment trial for doctors to commence in patients with insomnia and a picture of hyperventilation. It would be expected to give clinical improvement once the dose restores sleep, confirming the likely diagnosis and avoiding time away from work with protracted symptoms and possibly unwarranted investigations and referrals.
\end{abstract}

Abbreviations: COPD: Chronic Obstructive Lung Disease; A\&E: Accident and Emergency; HVS-Hyperventilation Syndrome; SWS: Slow Wave Sleep; ECG: Electrocardiogram; ECHO: Echocardiogram; $\mathrm{CO}_{2}$ : Carbon dioxide

\section{Introduction}

Anxiety-induced hyperventilation syndrome (HVS) is common, affecting $10 \%$ of the population with a female predominance and maybe continuous or episodic [1,2]. It forms part of the "dysfunctional breathing" group which includes vocal cord dysfunction, phobic disorders and panic attacks most of which are associated with hyperventilation [3]. Dysfunctional breathing arises frequently in asthma and chronic obstructive pulmonary disease (COPD) affecting up to $20 \%$ of patients. Only a small percentage of patients with hyperventilation seek medical attention. When they do, they attribute the symptoms to a more sinister cause for which they seek help; leading to frequent hospital attendances with expensive medical investigations often without early recognition of the true diagnosis.

The classic symptoms of acute HVS are those of dizziness or lightheadedness, chest tightness or chest pains along with shortness of breath, anxiety and occasional paraesthesia [1].

In chronic HVS, a dry mouth from hyperventilation leads to coughing along with the complaint of shortness of breath at rest and minimal exertion [4,5]. Many of these symptoms are unrelated to hypocapnia. Vague chest pains and chest tightness are common and ST segment depression of the ECG with repolarization abnormalities occur in up to $80 \%$ of cases [6-8].

In chronic HVS, the body's buffering system compensates and arterial carbon dioxide $\left(\mathrm{CO}_{2}\right)$ is usually normal, unlike those with acute HVS [4]. Hypocarbia $(<4.7 \mathrm{kPa})$ can give bronchoconstriction and reduce cerebral blood flow. Ambulatory monitoring in HVS shows carbon-dioxide to be generally normal with symptoms unrelated to Hypocarbia $[2,5,9,10]$. This suggests it is a consequence rather than a cause of an attack [5].

The Nijmegan questionnaire [2] for HVS has been used as a research tool to recognize the conditions with scores $>23$ indicative of the condition (Table 1).

A 3 minute voluntary "hyperventilation provocation test" causes symptoms in $>50 \%$ of patients with HVS $[5,9]$. These patients show a short breath-holding time (21secs versus 58 secs in controls) [11]. After exercise, blood lactate and respiratory minute volume are slower to recovery than controls [7] adding to the complaint of shortness of breath $[1,2]$. Table ii lists the commonest reported symptoms and recognized causes.

Freud recognized that anxious patients reported "an inability to get enough air in their lungs" with a feeling of oppression or suffocation

Correspondence to: Veronica A. Varney, Respiratory Department, St. Helier Hospital, Wrythe lane Carshalton, Surrey, SM5 1AA, U.K, Tel: 00-44-0(2)08 296 2401; Fax: 00-44-0(2)08 296 3163; E-mail: veronica.varney@esth.nhs.uk; veronica.varney@btinternet.com

Key words: anxiety, nijmegan questionnaire, hyperventilation syndrome, amitriptyline serotonergic neurons, panic disorder

Received: July 17, 2016; Accepted: July 30, 2016; Published: August 02, 2016 
Table 1. Example of questions in Nijmegen questionnaire [2].

Nijmegen Questionnaire

A score of over 23 out of 64 suggest a positive diagnosis of hyperventilation syndrome

\begin{tabular}{|c|c|c|c|c|c|}
\hline & $\begin{array}{c}\text { Never } \\
0\end{array}$ & $\begin{array}{c}\text { Rarely } \\
1\end{array}$ & $\begin{array}{c}\text { Sometimes } \\
2\end{array}$ & $\begin{array}{c}\text { Often } \\
3\end{array}$ & $\begin{array}{c}\text { Very Often } \\
4\end{array}$ \\
\hline \multicolumn{6}{|l|}{ Chest pain } \\
\hline \multicolumn{6}{|l|}{ Feeling tense } \\
\hline \multicolumn{6}{|l|}{ Blurred vision } \\
\hline \multicolumn{6}{|l|}{ Dizzy spells } \\
\hline \multicolumn{6}{|l|}{ Feeling confused } \\
\hline \multicolumn{6}{|c|}{ Faster or deeper breathing } \\
\hline \multicolumn{6}{|l|}{ Short of breath } \\
\hline \multicolumn{6}{|c|}{ Tight feelings in chest } \\
\hline \multicolumn{6}{|c|}{ Bloated feeling in stomach } \\
\hline \multicolumn{6}{|l|}{ Tingling fingers } \\
\hline \multicolumn{6}{|c|}{ Unable to breathe deeply } \\
\hline \multicolumn{6}{|c|}{ Stiff fingers or arms } \\
\hline \multicolumn{6}{|c|}{ Tight feelings round mouth } \\
\hline \multicolumn{6}{|l|}{ Cold hands or feet } \\
\hline \multicolumn{6}{|l|}{ Palpitations } \\
\hline Feeling of anxiety & & & & & \\
\hline
\end{tabular}

leading to sighing respiration [12,13]. Agoraphobia, phobic avoidance and obsessive-compulsive disorder have a higher prevalence in HVS with poor adaptation to stress $[5,7,14]$.

The diagnosis of HVS can be difficult as these symptoms are common to other diseases and often lead to multiple investigations and treatments. HVS has strong links to anxiety and depression giving multiple symptoms yet little evidence of physical disease $[7,15]$. There is a need to understand and avoid a misdiagnosis of serious organic disease by establishing whether the increased respiratory drive is organic or psychogenic. $17 \%$ of HVS patients recognize the condition themselves due to prior episodes, while $48 \%$ believe it represents heart disease [16]. There is no standard test for HVS which may contribute to under diagnosis [9] (Table 2).

\section{Case 1 (Table 3)}

Gave a 2 month history of increasing shortness of breath at rest and on exertion, which had rapidly deteriorated with fatigue, weakness and exhaustion associated with insomnia and sweats. He was unable to go to work and described the onset as after an acute sore throat associated with a constant cough and increasing breathlessness. His GP had prescribed asthma treatment in the form of prednisolone (oral and inhaled), salbutamol, 3 courses of antibiotics and omeprazole to no avail. His CXR and ECG were normal.

In outpatients he appeared anxious, grey, sweaty and hyperventilating and felt too weak to climb onto the examination couch. He had a nervous "throat clearing habit". His chest was clear without evidence of hyperinflation, vocal cord dysfunction, stridor or wheeze. Clinically there were no signs of venous thrombosis and oxygen saturations were $99 \%$ on air. Spirometry was above predicted and a walking test was performed to observe his saturations, heart rate and breathing under exercise. He walked the hospital corridors including 8 flights of stairs with ongoing hyperventilation only and a regular heart rate.

He was informed that everything pointed to stress that can result in hyperventilation and all the symptoms he described. When asked about stressful problems he revealed a pending employment review because of excessive time off with back ache which coincided with the
Table 2. Commonest symptoms and related risk factors in consecutive cases presenting to A\&E [16]

\begin{tabular}{|l|c|}
\hline Anxiety induced hyperventilation & Reported frequency of complaints \\
\hline Shortness of breath & $61 \%$ \\
\hline Chest pain/tight chest & $43 \%$ \\
\hline paresthesia & $35 \%$ \\
\hline panic & $30 \%$ \\
\hline dizziness & $13 \%$ \\
\hline palpitations & $13 \%$ \\
\hline Muscle spasms or weakness & $9 \%$ \\
\hline Recognized risk factors in addition to \\
anxiety & Frequency of risk factor \\
\hline Fear of heart disease or other serious disease & $87 \%$ \\
\hline Undiagnosed asthma & $30 \%$ \\
\hline Alcohol, cocaine, marijuana use & $17 \%$ \\
\hline
\end{tabular}

onset of the hyperventilation. All his asthma treatment was stopped and amitriptyline commenced at $10 \mathrm{mg} 2 \mathrm{hrs}$ before bed with instructions to increase the dose by $10 \mathrm{mg}$ every week (maximum $75 \mathrm{mg}$ nocte) until his sleep corrected. A ventilation/perfusion scan returned normal and at 4 week review all symptoms were gone and sleep was normal on amitriptyline $20 \mathrm{mg}$ nocte. He was advised to stay on treatment for at least 3-6 months or longer if work stress continued. He was discharged to his GP.

\section{Case 2 (Table 3)}

Gave a 3 month history of a rapidly progressive breathlessness on exertion. There were no symptoms of cough, chest tightness, sputum production, wheeze or leg swelling. The onset started immediately after 2 family members moved into their 2 bedroom house, bringing with them 4 dogs, rabbits, guinea pigs and a parrot. All pets were living indoors due to the lack of an outside sheds. Despite eczema he had no past history of asthma or allergies. His GP felt this may be allergy to the pets or a bird fanciers lung. All the specific IgE tests returned negative along with avian precipitins to parrot and pigeon. His CXR showed a raised Right hemi-diaphragm with clear lung fields. His eosinophils count and natriuretic peptide were also normal along with his ECG. After 3 months off work and trials of asthma treatments to no avail he was referred to respiratory outpatients. 
Table 3. Demographics of cases 1-6.

\begin{tabular}{|c|c|c|c|c|c|c|}
\hline Cases & 1 & 2 & 3 & 4 & 5 & 6 \\
\hline Age (sex) & $49(\mathrm{~m})$ & $65(\mathrm{~m})$ & $84(f)$ & $50(\mathrm{~m})$ & $16(f)$ & $55(\mathrm{f})$ \\
\hline Ethic Group + & $\mathrm{C}$ & $\mathrm{C}$ & $\mathrm{C}$ & $\mathrm{C}$ & $\mathrm{C}$ & $\mathrm{C}$ \\
\hline $\begin{array}{l}\text { Smoking } \\
\text { (pack yrs) }\end{array}$ & $\begin{array}{c}\text { Ex-7yr } \\
(15)\end{array}$ & $\begin{array}{c}\text { Ex-8yr } \\
(30)\end{array}$ & Passive only & $\begin{array}{c}\text { Ex-2yr } \\
(15)\end{array}$ & nil & $\begin{array}{l}\text { ex-15yrs } \\
(20)\end{array}$ \\
\hline ETOH (units/wk) & $>21$ & nil & nil & $>21$ & nil & 2 \\
\hline Past Medical History \# & $\begin{array}{c}\text { HTN } \\
\text { cholesterol } \\
\text { DU } \\
\text { Back pain }\end{array}$ & $\begin{array}{c}\text { AF } \\
\text { Eczema } \\
\text { Fall from height } 12 \text { yrs ago } \\
\text { with fractures to arm and } \\
\text { shoulder }\end{array}$ & $\begin{array}{c}\text { COPD } \\
\text { IHD } \\
\text { cholesterol } \\
\text { Glaucoma }\end{array}$ & $\begin{array}{l}\text { Childhood } \\
\text { asthma }\end{array}$ & Migraine & $\begin{array}{l}\text { Mild asthma } \\
\text { atopic } \\
\text { rhinitis } \\
\text { hypothyroid }\end{array}$ \\
\hline Chest X Ray & normal & Raised Rt diaphragm & normal & normal & normal & Normal \\
\hline Blood tests* & normal & normal & normal & normal & normal & Normal \\
\hline ECG & - & ECG normal & normal & normal & normal & Normal \\
\hline ECHO & - & - & normal & normal & normal & - \\
\hline Respiratory Rate (bpm) at rest & 24 & 22 & 24 & 24 & 22 & 22 \\
\hline Oxygen saturations at rest & $99 \%$ & $99 \%$ & $99 \%$ & $98 \%$ & $100 \%$ & $98 \%$ \\
\hline Desaturation on exercise & no & no & no & no & no & no \\
\hline PEFR (\% predicted) & $159 \%$ & $81 \%$ & - & $140 \%$ & - & $105 \%$ \\
\hline FEV-1 (\% predicted) & $125 \%$ & $146 \%$ & $53 \%$ & $120 \%$ & - & $96 \%$ \\
\hline FVC $(\%$ predicted $)$ & $109 \%$ & $113 \%$ & $108 \%$ & $110 \%$ & - & $102 \%$ \\
\hline $\begin{array}{l}\text { Duration of } \\
\text { Symptoms (months) }\end{array}$ & 2 & 3 & 3 & 4 & 5 & 8 \\
\hline Main complaint $\Delta$ & $\begin{array}{l}\text { Weak, SOB, sweaty } \\
\text { exhausted }\end{array}$ & $\begin{array}{l}\text { Weak, SOB, sweaty } \\
\text { exhausted }\end{array}$ & $\begin{array}{c}\text { SOBOE }++ \\
\text { To leave the house }\end{array}$ & $\begin{array}{l}\text { Difficulty } \\
\text { Breathing in and } \\
\text { SOBOE }\end{array}$ & $\begin{array}{c}\text { SOBOE } \\
\begin{array}{c}\text { Palpitations and localised } \\
\text { chest wall pain }\end{array}\end{array}$ & $\begin{array}{c}\text { SOBOE } \\
\text { Chest pain }\end{array}$ \\
\hline Past anxiety or depression & no & $\begin{array}{c}\text { Teeth grinding } \\
\text { at night, claustrophobia }\end{array}$ & anxiety & no & no & anxiety \\
\hline Panic attacks currently & no & In crowds & yes & yes & yes & Yes \\
\hline Presence of insomnia & yes & yes & yes & yes & yes & Yes \\
\hline $\begin{array}{l}\text { Time off work due } \\
\text { To symptoms (weeks) }\end{array}$ & 8 & 12 & retired & No & Off school & No \\
\hline No. of GP visits & 4 & 7 & 3 & 3 & 7 & 3 \\
\hline Working diagnosis by GP & asthma & Bird fanciers lung/asthma & COPD or heart failure & $\begin{array}{c}\text { Pulmonary } \\
\text { hypertension }\end{array}$ & $\begin{array}{l}\text { Atypical chest pain and } \\
\text { palpitations }\end{array}$ & Asthma \\
\hline Prior treatment from GP & $\begin{array}{c}\text { Prednisolone, Clenil, } \\
\text { salbutamol, antibiotics X } 3\end{array}$ & $\begin{array}{l}\text { Prednisolone, salbutamol, } \\
\text { seretide }\end{array}$ & Seretide, tiotropium & $\begin{array}{l}\text { Antibiotics } \\
\text { steroids }\end{array}$ & Anti-inflammatory drugs & $\begin{array}{l}\text { steroids inhalers } \\
\text { proton pump } \\
\text { inhibitors } \\
\text { antibiotics }\end{array}$ \\
\hline A\&E attendances & 0 & 1 & 2 & 2 & 4 & 0 \\
\hline Hospital admissions & 1 & 0 & 1 & 0 & 1 & 0 \\
\hline No of outpatient referrals & 2 & 3 & 2 & 3 & 2 & 2 \\
\hline Chest clinic diagnosis & HVS & HVS & HVS & HVS & HVS & HVS \\
\hline $\begin{array}{l}\text { Likely Cause of } \\
\text { hyperventilation }\end{array}$ & Work stress & Family stress & Household stress & Family bereavement & Fear of heart disease & Bereavement \\
\hline $\begin{array}{l}\text { Dose of amitriptyline } \\
\text { to settle symptoms (mg) }\end{array}$ & 20 & 30 & 10 & 10 & 10 & $10 \mathrm{mg}$ \\
\hline $\begin{array}{l}\text { Time to benefit } \\
\text { from amitriptyline (weeks) }\end{array}$ & 1 & 3 & 1 day & 3days & 3days & 1 \\
\hline
\end{tabular}

In outpatients he was noted to be "grinding his teeth" every few minutes. He looked anxious and confirmed poor sleep in the prior 3 months and when asked admitted that he had found life very stressful since the family and pets moved in. Physical examination revealed shaky hands with general sweating. The raised diaphragm was minor but clinically detectable by dullness at the right base otherwise the lung fields were clear. Oxygen saturations and spirometry were above predicted and he developed no desaturation or wheezes on a walking test.

The explanation for the raised diaphragm was probably a very nasty fall from the attic 12 yrs before in which his suffered fractures and a shoulder injury but there was no prior CXR for comparison.
The working diagnosis was anxiety-induced hyperventilation and he was commenced on amitriptyline $10 \mathrm{mg} 2 \mathrm{hrs}$ before bed and told to increase each week until sleeping soundly (maximum dose $75 \mathrm{mg}$ nocte). Thyroid function tests were checked urgently in view of the sweats and hand shakes and returned normal. Nothing in the history suggested a phaeochromocytoma. A Staging CT chest and formal lung function tests were arranged. At review all lung volumes were above predicted including spirometry and transfer factors. The C.T. chest scan showed no pathology. The patient reported that all symptoms had resolved on $30 \mathrm{mg}$ of amitriptyline and he was calm, no longer grinding his teeth or hyperventilating and sleeping well. It was suggested that he remain on amitriptyline until the household stress was sorted out. 


\section{Case 3 (Table 3)}

This lady had attended A\&E twice with breathlessness of 4 months duration. Prior to this she had been independent to the shopping centers and visiting friends and family on a daily basis without any limitation inside or outside the house. In A\&E her oxygen saturations were raised and her CXR clear so she was generally discharged with antibiotics which gave no benefit. As things deteriorated she became unable to neither leave the house nor complete her activities of daily living and was admitted to hospital at the GP's request when inhalers for COPD gave no benefit.

On the acute medical unit the working diagnosis was severe COPD, despite only passive smoking in the past and no prior respiratory symptoms unless she had a nasty virus. When treatments with steroids and nebulizers gave no benefit we were asked to review.

The history revealed the onset of the breathlessness to be sudden and to coincide with a gas leak in her house which required urgent attention. It had been the first household emergency since her husband death but had left her feeling nervous in the house and in dread that something else would go wrong next. Total insomnia had developed since this event and her rapid breathing associated with a dry mouth had begun. Her family described her as a born worrier.

Physically she looked very anxious and unable to relax with marked hyperventilation at rest but otherwise examination was unremarkable. She was nervous about walking down the hospital corridor despite her normal saturations. It was explained that this was anxiety induced hyperventilation and that we would commence her on amitriptyline. The next morning she confirmed that she had slept well and her respiratory rate was clearly normal at rest and she walked the whole hospital corridor without difficulty. She was discharged on amitriptyline with outpatient review. At review she was out and about again with her family and gaining confidence go out on her own. She was told to remain on the amitriptyline indefinitely as she now disliked being in the house alone. Her ECG and cardiac echo were normal.

\section{Case 4 (Table 3)}

Gave a 4 month history of requiring "extra breaths" along with shortness of breath. He noticed this by day but it became more pronounced in the evening and overnight occurring then at rest. In outpatients he was clearly hyperventilating. On questioning, the onset had occurred after his mother's recent death from pulmonary hypertension. Discussion of this made him upset and he re-expressed the fear that he may now have lung cancer due to past smoking. He admitted to insomnia and despite his symptoms he was still working as a fireman.

He had regular asthma treatments from childhood with no symptoms of cough or wheeze and his GP had excluded cardiac disease and early pulmonary hypertension with an ECG and ECHO. On exercise he showed no desaturation and was reassured that a CXR showed no lung cancer. He was asked to commence amitriptyline and increase the dose until he was sleeping well. At 4 week review, all his symptoms had settled and he had realized that this was all anxiety and effects of bereavement and was using "mind over matter". As a result he had stopped the amitriptyline after 2 weeks and had remained well. He was discharged.

\section{Case 5 (Table 3)}

This school girl was admitted to the hospital with unexplained left sided chest pain for 5 months associated with shortness of breath at rest and on exertion. She had had several A\&E attendances and hospital admissions with a referral to the cardiologists for symptoms of chest pain and chest tightness, intermittent palpitations, dizzy spells with vertigo along with significant breathlessness at 20 meters. She had already completed a treadmill test, $24 \mathrm{hr}$ ECG and echocardiogram all of which were normal.

Her pain was localized and corresponded with a jutting rib causing tietze syndrome. The cause of the pain was explained and injected locally with triamcinolone. She explained that the pain had made her fearful that she had heart disease which had affected her sleep and started her hyperventilating. She had been absent from school and unable to walk or exercise. Oxygen saturations were $100 \%$ at rest. She was commenced on amitriptyline $10 \mathrm{mg} 2 \mathrm{hrs}$ before bed and on review 3 days following discharge all symptoms had settled and the tietze syndrome pain improved dramatically. Both conditions were explained again and it was suggested that she remain on amitriptyline until her confidence was back and all cardiac tests completed. She was discharged to follow up by the cardiologists.

\section{Case 6 (Table 3)}

This patient presented with 4 months of chest pain associated with acid reflux symptoms and difficulty in breathing with wheeze. She gave a history of atopic rhinitis and mild asthma and treated hypothyroidism. As a result she was referred urgently to rapid access chest pain clinic and their investigation excluded angina. She failed to respond to steroids, asthma inhalers and antibiotics from her GP. Peak expiratory flow rate variation was $<13 \%$ with a methacholine test of $24 \mathrm{mg} / \mathrm{ml}$. Skin tests confirmed atopy. On a shuttle walking test she obtained level 10 out of 12 (700 metres) without oxygen desaturation and no change in pre- or post-walk peak flows. Vocal cord dysfunction was noted along with hyperventilation and this problem had followed a close family bereavement. She commenced amitriptyline $10 \mathrm{mg}$ and felt drowsy so the dose was reduced to $5 \mathrm{mg}$. Her symptoms subsided within the first week of amitriptyline and she was discharged back to the GP.

\section{Case 7 (Table 4)}

Gave a 3 month history of breathlessness with a dry mouth and feeling washed out and light headed. She had never smoked and had no respiratory diseases in the past. The onset of the condition had followed surgery for a new local recurrence of her melanoma originally diagnosed 2 yrs before. Her post op CT scans showed normal chest, abdomen and pelvic scans without pathology or lung disease. She had normally been independent but had developed insomnia post op and breathlessness that made her feel physically weak such that she wondered if she could remain independent at home. In outpatients she looked very panicky and was clearly hyperventilating. She had made 2 visits to $A \& E$ due to shortness of breath. At each visit no diagnosis was made as her chest $\mathrm{X}$ rays were clear and her oxygen levels raised and this ultimately led to chest clinic referral. Thyroid function was normal along with other blood tests. Hyperventilation syndrome was explained and amitriptyline commenced. At a dose of $20 \mathrm{mg}$ all symptoms resolved and her sleep became normal.

\section{Case 8 (Table 4)}

This lady was referred with shortness of breath for 2 yrs. A year before she had a diagnosis of physical deconditioning at another hospital. Her past medical history included pulmonary embolus following a knee 
Table 4. Demographics of cases 7-12.

\begin{tabular}{|c|c|c|c|c|c|c|}
\hline Cases & 7 & 8 & 9 & 10 & 11 & 12 \\
\hline Age (sex) & $88(\mathrm{f})$ & $76(f)$ & 73 (f) & $53(\mathrm{f})$ & $66(f)$ & $63(\mathrm{f})$ \\
\hline Ethic Group + & $\mathrm{C}$ & $\mathrm{C}$ & I & $\mathrm{C}$ & $\mathrm{C}$ & $\mathrm{C}$ \\
\hline $\begin{array}{l}\text { Smoking } \\
\text { (pack yrs) }\end{array}$ & nil & nil & nil & nil & $\begin{array}{c}\text { Ex } 6 \text { months } \\
(25)\end{array}$ & nil \\
\hline ETOH (units/Wk) & nil & nil & nil & 10 & nil & nil \\
\hline Past Medical History \# & $\begin{array}{l}\text { Melanoma } 2 \mathrm{yr} \\
\text { Recent block dissection } \\
\text { for recurrence }\end{array}$ & $\begin{array}{c}\text { HTN } \\
\text { TKR with post-op PE } \\
\text { SAH with memory effects }\end{array}$ & $\begin{array}{l}\text { Ca breast } \\
\text { DM-type-2 } \\
\text { MR, AF }\end{array}$ & $\begin{array}{l}\text { IHD, CABG } \\
\text { HTN, rhinitis } \\
\text { Chronic cough }\end{array}$ & $\begin{array}{c}\text { HTN } \\
\text { High cholesterol }\end{array}$ & $\begin{array}{l}\text { Parkinson's disease, reflux, } \\
\text { pneumonia } \\
\text { VATS for Lt-sided effusion }\end{array}$ \\
\hline Chest X Ray & normal & normal & normal & normal & normal & $\begin{array}{l}\text { Lt sided pleural change } \\
\text { post VATS }\end{array}$ \\
\hline Blood tests* & normal & normal & normal & normal & normal & normal \\
\hline ECG & normal & normal & $\mathrm{AF}$ & - & normal & normal \\
\hline ECHO & - & normal & $\begin{array}{l}\text { Mitral regurgitation, } \\
\mathrm{PAP}=31 \mathrm{mmhg}\end{array}$ & - & $\begin{array}{c}\text { Coronary angiogram } \\
\text { normal }\end{array}$ & - \\
\hline $\begin{array}{l}\text { Respiratory Rate (bpm) } \\
\text { at rest }\end{array}$ & 24 & 28 & 26 & 22 & 24 & 14 \\
\hline Oxygen saturations at rest & $99 \%$ & $96 \%$ & $99 \%$ & $100 \%$ & $98 \%$ & $96 \%$ \\
\hline Desaturation on exercise & nil & To $90 \%$ & nil & nil & nil & nil \\
\hline PEFR (\% predicted) & Poor technique & $89 \%$ & Poor technique & $105 \%$ & $92 \%$ & $86 \%$ \\
\hline FEV-1 (\% predicted) & Poor technique & $87 \%$ & Poor technique & $100 \%$ & $98 \%$ & $98 \%$ \\
\hline FVC $(\%$ predicted $)$ & Poor technique & $96 \%$ & Poor technique & $92 \%$ & $85 \%$ & $106 \%$ \\
\hline $\begin{array}{l}\text { Duration of } \\
\text { Symptoms (months) }\end{array}$ & 3 & 24 & 9 & $>24$ & 4 & 6 \\
\hline Main complaint & $\begin{array}{c}\text { Exhaustion and weak, } \\
\text { breathless at rest and } \\
\text { exercise }\end{array}$ & Breathless on any exertion & Extreme breathlessness & $\begin{array}{l}\text { Cough, breathless at } \\
\text { rest + exertion }\end{array}$ & $\begin{array}{l}\text { Extreme breathlessness } \\
\text { and tight chest }\end{array}$ & $\begin{array}{l}\text { Attacks of severe loss of } \\
\text { breathe, cough and dry } \\
\text { mouth }\end{array}$ \\
\hline Past anxiety or depression & no & no & yes & yes & yes & yes \\
\hline Panic attacks currently & Anxious & Anxious & No & No & 2008 & Not recognised \\
\hline Presence of insomnia & yes & yes & yes & yes & yes & yes \\
\hline $\begin{array}{l}\text { Time off work due } \\
\text { To symptoms (weeks) }\end{array}$ & retired & retired & retired & no & retired & retired \\
\hline No. of GP visits & 1 & 4 & 2 & 2 & 4 & 3 \\
\hline Working diagnosis by GP & unsure & pulmonary embolus & Likely asthma or COPD & $\begin{array}{c}\text { Cough and possible } \\
\text { asthma }\end{array}$ & COPD & Pneumonia recurrence \\
\hline Prior treatment from GP & antibiotics & nil & Inhalers for asthma & $\begin{array}{c}\text { Acid block } \\
\text { Antibiotics, steroids }\end{array}$ & $\begin{array}{l}\text { Seretide } \\
\text { tiotropuim }\end{array}$ & $\begin{array}{l}\text { antibiotics } \\
\text { acid block }\end{array}$ \\
\hline A\&E attendances & 4 & 0 & 1 & 2 & 4 & 2 \\
\hline Hospital admissions & 0 & 0 & 0 & 0 & 3 & 0 \\
\hline No of outpatient referrals & 2 & 2 & 3 & 4 & 3 & 3 \\
\hline Chest clinic diagnosis & HVS & HVS & HVS & HVS & HVS & HVS \\
\hline $\begin{array}{l}\text { Likely Cause of } \\
\text { hyperventilation }\end{array}$ & Post-operative stress & Free-floating & $\begin{array}{l}\text { Cardiac disease } \\
\text { phobia }\end{array}$ & Fear of illness & Smoking cessation & Fear of illness \\
\hline $\begin{array}{l}\text { Dose of amitriptyline } \\
\text { to settle symptoms (mg) }\end{array}$ & 20 & 10 & 10 & 20 & 20 & 20 \\
\hline $\begin{array}{l}\text { Time to benefit } \\
\text { from amitriptyline (weeks) }\end{array}$ & 1 & 1 & 1 & 1 & 8 & 2 \\
\hline
\end{tabular}

* FBC, U\&E, LFT, Ca, protein, CRP and thyroid function,

$+\mathrm{C}=$ caucausian, $\mathrm{I}=$ Indian.

\# HTN-hypertension. TKR-total knee replacement.

SAH-sub-arachnoid haemorrhage.DM-diabetes mellitus. MR-mitral regurgitation. AF- atrial fibrillation.

IHD-ischaemic heart disease.

CABG-coronary bypass graph.

replacement and early retirement with some memory impairment after a subarachnoid haemorrhage years before. She had never smoked and had no prior respiratory disease. Physical examination was normal but she had hyperventilation with a respiratory rate of $28 / \mathrm{min}$ along with constant nervous fidgeting with her hands and humming. No desaturation on exercise occurred and sleep was confirmed to be poor. Exercise had been recommended the year before but not completed. Amitriptyline $10 \mathrm{mg}$ was commenced. A CT chest scan showed normal lung architecture and her lung function tests were entirely normal.

On review her breathlessness had resolved and her sleep was normal. Her hand fidgeting and nervous humming had ceased to the relief of her family.

\section{Case 9 (Table 4)}

This lady was referred by GP with extreme breathlessness at rest and on exertion, despite a normal CXR and no other specific chest symptoms. In the past she had a left sided pleuradesis following pneumonia with pleural biopsies showing fibrosis scars only. She was also diabetic and on regular follow up for her breast cancer. The cardiac clinic monitored her atrial fibrillation and mitral regurgitation, and 
a recent echo gave a pulmonary artery pressure of $31 \mathrm{mmhg}$ with a normal ejection fraction.

On meeting this lady she looked depressed and anxious and admitted to taking no exercise in the form of walking over a long time with fears relating to her heart condition. She could not sleep and was up most of the night with insomnia and leg cramps. She had a steady heart rate and high oxygen saturations at rest which continued on exertion including several flights of stairs.

Hyperventilation was explained and she was commenced on amitriptyline and told to increase the dose by $10 \mathrm{mg}$ until she was sleeping well.

On review at 6 weeks, her CT chest scan was normal, without any breast cancer recurrence. She was sleeping well and all hyperventilation had ceased along with night cramps. She was walking 30 minutes a day and looked and felt healthy and was discharged.

\section{Case 10 (Table 4)}

Referred by her GP with a cough for 5 yrs but also increasing shortness of breath at rest. She was on ramipril for high BP which was changed to candesartan in view of her cough. She had hyperventilation at rest and admitted to significant insomnia along with a rhinitis and blocked nose from childhood. Skin testing showed no atopy and we commenced avamys nasal spray and amitriptyline $10 \mathrm{mg}$ at night. She was asked to complete a peak flow diary and increase the amitriptyline until she was sleeping well. She attended the fibreoptic list 3 weeks later for examination of the nose and throat and reported that all hyperventilation had ceased and she was better and sleeping well. Acid reflux changes were seen in the epiglottis and vocal cords but no polyps nor sinus discharge. She was commenced on omeprazole $20 \mathrm{mg}$ at 6 $\mathrm{pm}$ and advised to continue amitriptyline until review. On review her cough had settled off ramipril and with the addition of omeprazole. Sleep was normal on amitriptyline and the hyperventilation had resolved. Retrospectively, she realized she had become anxious about herself due to the cough with fear of it being a serious disease. She was reassured and discharged.

\section{Case 11 (Table 4)}

This lady was referred by her GP after an attendance for dizziness and persistent shortness of breath on exertion. She was assessed in $\mathrm{A} \& \mathrm{E}$ where her $\mathrm{BP}$ and heart rate were noted to be raised with oxygen saturations of $98 \%$ on air. Her BP and heart rate settled spontaneously with ongoing monitoring. She attended $A \& E$ a total of 4 times with breathlessness, dizziness and parasthesia leading to 3 admissions. $24 \mathrm{hr}$ Blood Pressure monitoring showed normal pressure and the working diagnosis was COPD despite normal spirometry, total lung capacity, vital capacity and diffusion. The patient had given up smoking 6 months before just as her symptoms began. On review by the respiratory nurses, the inhalers (tiotropium and seretide) were stopped. Peak flow variation was $<13 \%$ and the patient was taking metoprolol $100 \mathrm{mg}$ daily and ramipril $5 \mathrm{mg} /$ day for high blood pressure. Her husband felt she was anxious and needed to control everything and had become more anxious since she gave up smoking. Insomnia was present and past panic attacks had occurred. After amitriptyline $(20 \mathrm{mg})$ for 4 weeks, her symptoms had resolved and she was sleeping well. She then commenced swimming and aqua aerobics in order to reverse the weight gain from smoking cessation. She was reassured and discharged back to the GP.

\section{Case 12 (Table 4)}

This lady was referred urgently due to a dry cough and episodes of loss of breath, worse on bending and lying flat, along with a dry mouth. Her barium swallow was normal without evidence of a hiatus hernia and she was asked to increase her water intake as 3 of her 4 drugs for Parkinson's disease could dry her mouth. A past pneumonia associated with a para-pneumonic effusion 2 yrs before, had increased her anxiety levels every time she developed a viral illness due to fear that she may have a further episode of pneumonia. This had affected her sleep and she had developed episodes of hyperventilation with a distinct feeling of panic especially in the evening and at night when she was alone. This HVS had not settled even after the virus had cleared. HVS was explained and amitriptyline commenced. On review the complaint of cough had resolved with increased water intake and amitriptyline 20 mg had settled the panic attacks completely with normal sleep. She was reassured and discharged.

\section{Discussion}

Excessive respiratory drive above physiological requirement is still a poorly understood condition despite it's relatively high frequency in society with relatively little recent research or publications.

Our cases illustrate the difficulty in making the diagnosis prior to referral with arterial gases seldom measured even in A\&E due to the raised oxygen saturations at rest $>98 \%$. Yet this along with a clear chest $\mathrm{x}$ ray and a raised respiratory rate did not appear to suggest possible hyperventilation to the doctors.

There also appears to be a lack of clear history taking to determine the exact circumstances at onset of the condition and any other associated anxiety, insomnia and panic. This is especially important as generally there was no significant respiratory disease prior to the problem in 9 out of 12 cases. Most patients also looked extremely anxious in outpatients with many nervous habits observable. Most cases had above expected spirometry results along with laboratory based lung function which was also not appreciated by the referring doctors, yet could have assisted them in excluding severe obstructive lung disease as the diagnosis. The tendency to good lung function may contribute to the symptoms of HVS by way of an increased minute volume. A Nijmegan questionnaire (Table 1) and a breath hold test maybe useful for GP's, as all cases described here would have scored highly on this questionnaire. A trial of more appropriate treatments could have commenced earlier avoiding sickness absence from work and multiple outpatient referrals and investigations including $A \& E$ attendances and hospital admission.

From our 12 cases there were a total of 22 A\&E attendances, 6 hospital admissions and 31 outpatient referrals. 43 GP consultations also occurred.

The standard treatment for HVS $[1,2,17,18]$ has been reassurance, relaxation exercises and specific breathing retraining including diaphragm breathing to reduce rate and depth and this is still advocated in the 2009 British Thoracic society guidelines [19]. Studies have shown that 6 months of exercise training is required with regular input at home [3]. Large reviews show no benefit even with $2 \mathrm{hrs}$ of breathing exercise a day $[3,20]$. The belief that low $\mathrm{CO}_{2}$ is primary to the condition ignores the evidence that normocapnia can trigger symptoms also. In anxiety and asthma the Buteyko breathing technique $[17,20]$ is successful in reducing symptoms with sufficient practice, but many patients do not have the self control and perseverance required for regular and lengthy breathing exercises [2]. Reduced self awareness of breathing effort may require biofeedback devices to be effective [4].

The mechanism that underpins HVS $[1,11]$ is poorly understood. 
The respiratory centre in the medulla and pons has a respiratory pacemaker and provides inherent respiratory rhythmicity upon which other influences are imposed [7]. The respiratory centre can been overridden by behavioral and volitional factors from the motor cortex, influenced by the reticular activating system and limbic system which sub serves sleep, arousal and emotional states. In addition, the thalamus may have a role in regulating ventilation as a group of neurons fire in synchrony with respiration and are affected by hypercapnia [21]. The thalamus contains a very high density of mu-opioid receptors which depress respiration. Central neurogenic hyperventilation is seen in brain stem injury usually with reduced consciousness, but also with brain tumours of the pons and medulla, small vessel infarcts of the brain stem and even lymphomas of the hypothalamus and mid-brain [21].

Research suggests a primary abnormality in respiratory control is unlikely [22] and it is proposed that excessive reactivity maybe a better explanation as "hypersensitive fear neurocircuitary" [15]. Recent neuro-imaging suggests significant overlap in neural circuitry of airhunger and anxiety $[22,23]$. Papp proposed a set point for the brain stem chemoreceptor's that are deranged in panic disorder patients [24]. This set point could be lowered by hypocarbia or anxiety to produce numerous "suffocation alarms" causing panic attacks [25]. Respiratory disorders of the lower airway such as asthma or COPD may cause derangement of the respiratory set point causing the high incidence of HVS in these conditions. The theory of suffocation false alarms gives HVS a secondary role in panic disorder. Normocapnia or hypercapnia may trigger suffocation alarms causing dyspnoea and HVS; which could explain why chronic HVS patients keep their arterial $\mathrm{CO}_{2}$ lower than controls and away from the suffocation alarm point. A rise in arterial $\mathrm{CO}_{2}$ (not a fall) is the most likely trigger of panic [25]. Research shows that HVS patients given an increased inspired fraction of $\mathrm{CO}_{2}$ develop panic, yet carbon dioxide and oxygen sensitivity appears normal in most patients with HVS suggesting the drive may not be cortical [10]. This is supported by studies showing that subjects with HVS exercised under hyperoxic and hypercapnic conditions (50\% oxygen, $5 \%$ carbon dioxide, $45 \%$ nitrogen) had sustained HVS with dyspnoea compared with controls [11]. Suggesting that central chemoreceptors are not responsible and therefore questions whether this is the respiratory makeup of the individual [11].

There is general agreement that under conditions of psychological stress [7] increased respiratory rate and tidal volume occurs. HVS patients may have over reactivity of the respiratory centre compared healthy controls giving a greater susceptibility to over breathe in stressful situations. Drug therapy in HVS is the subject of very few reports. One report of the Tricyclic drug clomipramine is described [26]. Six patients with an average $3.4 \mathrm{yr}$ history of HVS, who all failed 2 yrs of behavior therapy along with benzodiazepines drugs, were commenced on Clomipramine $25 \mathrm{mg} 8 \mathrm{hrly}$. HVS and anxiety reduced at 3-4 weeks with phobia decreasing over 2 months and treatment was discontinued by 9 months without relapse at 2 yrs. It was felt that clomipramine's enhancement of serotonergic neurons had produced respiratory depression and alleviated the hyperventilation, anxiety and fear via increased serotonergic activity [27]. A similar observation was made by Klein using the tricyclic drug Impramine in extremely anxious patients with panic disorder and hyperventilation refractory to tranquillizers and phenthiazines [28].

Lowered serotonin in experimental animal models is associated with anxiety and fear [29]. These authors suggest that the lowering of $\mathrm{CO}_{2}$ sensitivity during slow wave sleep (SWS) is the likely mechanism, since serotonergic neurons are considered crucially active then and are important in respiratory depression including ethanol intoxication $[11,30]$. It is suggested that tricyclic drugs could reverse HVS in a physiological way through their improvement in brain serotonin and then subsequently be discontinued [31]. Ebuehi previously reported that malnutrition, marijuana smoking and ethanol consumption all decreased serotonin in experimental animals [32-34], while the tricyclic drugs (Impramine or amitriptyline) produces a more pronounced increase in brain serotonin levels compared with antidepressants such as sertraline [35]. These observations suggest that serotonin is important in the condition of HVS and offers a possible explanation for the observed benefits of amitriptyline. Sheehan suggests that hyperventilation and panic is currently viewed as over-reaction to life's stresses or an unconscious conflict. He believed this concept should be revised; as a likely biochemical abnormality in the nervous system to which there may be genetic vulnerability explaining its sudden appearance without warning often in youth along with a family tendency [36]. This case series suggests a possible treatment via the restoration of SWS and possible effects of increased brain serotonin offering a treatment that appears rapidly effective in comparison to specific breathing retraining. Further studies of retraining versus tricyclic drugs would be of interest as so little therapeutic data is available for this condition and it can present to so many specialties.

\section{References}

1. Gavish B (2010) Device-guided breathing in the home setting: technology, performance and clinical outcomes. Biol Psychol 84: 150-156.[Crossref]

2. Thomas M, McKinley RK, Freeman E, Foy C (2001) Prevalence of dysfunctional breathing in patients treated for asthma in primary care: cross sectional survey. $B M J$ 322: 1098-1100.[Crossref]

3. Preter M, Klein DF (2008) Panic, suffocation false alarms, separation anxiety and endogenous opioids. Prog Neuropsychopharmacol Biol Psychiatry 32: 603-612. [Crossref]

4. Clark DM, Salkovskis PM, Chalkley AJ (1985) Respiratory control as a treatment for panic attacks. J Behav Ther Exp Psychiatry 16: 23-30.[Crossref]

5. Hornsveld H, Garssen B, Dop MF, van Spiegel P (1990) Symptom reporting during voluntary hyperventilation and mental load: implications for diagnosing hyperventilation syndrome. J Psychosom Res 34: 687-697.[Crossref]

6. Mortensen SA, Vilhelmsen R, Sandøe E (1983) Non-pharmacological provocation of coronary vasospasm. Experience with prolonged hyperventilation in the coronary care unit. Eur Heart J 4: 391-397.[Crossref]

7. Bass C, Gardner W (1985) Emotional influences on breathing and breathlessness. $J$ Psychosom Res 29: 599-609.[Crossref]

8. Alexopoulos D, Christodoulou J, Toulgaridis T, Sitafidis G, Manias O, et al. (1996) Repolarization abnormalities with prolonged hyperventilation in apparently healthy subjects: incidence, mechanisms and affecting factors. Eur Heart J 17: 1432-1437. [Crossref]

9. Hornsveld HK, Garssen B, Dop MJ, van Spiegel PI, de Haes JC (1996) Double-blind placebo-controlled study of the hyperventilation provocation test and the validity of the hyperventilation syndrome. Lancet 348: 154-158. [Crossref]

10. Gardner WN (2004) Hyperventilation. Am J RespCrit Care Med 170:105-108.

11. Jack S, Rossiter HB, Pearson MG, Ward SA, Warburton CJ, et al. (2004) Ventilatory responses to inhaled carbon dioxide, hypoxia, and exercise in idiopathic hyperventilation. Am J Respir Crit Care Med 170: 118-125.[Crossref]

12. Evans L (1988) The importance of cognitions in panic attacks.Behavior Therapy 23 471-483.

13. Finesinger JE (1937)Effects of pleasant and unpleasant ideas on respiration in psychoneurotic patients. Arch Neurpsych 42: 425-490.

14. Boiten FA, Frijda NH, Wientjes CJ (1994) Emotions and respiratory patterns: review and critical analysis. Int J Psychophysiol 17: 103-128.[Crossref]

15. Sinha S, Papp LA, Gorman JM (2000) How study of respiratory physiology aided our understanding of abnormal brain function in panic disorder. $J$ Affect Disord 61: 191200.[Crossref] 
16. Saisch SG, Wessely S, Gardner WN (1996) Patients with acute hyperventilation presenting to an inner-city emergency department. Chest 110: 952-957.[Crossref]

17. Thomas M, McKinley RK, Freeman E, Foy C, Prodger P, et al. (2003) Breathing retraining for dysfunctional breathing in asthma: a randomised controlled trial. Thorax 58: 110-115.[Crossref]

18. Jones M, Harvey A, Marston L, O’Connell NE (2013) Breathing exercises for dysfunctional breathing/hyperventilation syndrome in adults. Cochrane Database Syst $\operatorname{Rev}$ CD009041.[Crossref]

19. BTS/ACPRC Concise guidelines(2009)Physiotherapy management of the adult, medical, spontaneously breathing patient.Appendix 5- Respiratory physiotherapy for people with hyperventilation syndrome or disordered breathing.

20. Johansen T, Jack S, Dahl R (2013) Normalizing C02 in chronic hyperventilation by means of a novel breathing mask: a pilot study.ClinRespir J 7: 359-366. [Crossref]

21. Johnston SC, Singh V, Ralston HJ 3rd, Gold WM (2001) Chronic dyspnea and hyperventilation in an awake patient with small subcortical infarcts. Neurology 57: 2131-2133.[Crossref]

22. Simon NM, Weiss AM, Kradin R, Evans KC, Reese HE, et al. (2006) The relationship of anxiety disorders, anxiety sensitivity and pulmonary dysfunction with dyspnearelated distress and avoidance. J Nerv Ment Dis 194: 951-957.[Crossref]

23. Evans KC, Banzett RB, Adams L, McKay L, Frackowiak RS, et al. (2002) BOLD fMRI identifies limbic, paralimbic, and cerebellar activation during air hunger. $J$ Neurophysiol 88: 1500-1511.[Crossref]

24. Papp IA, Klein DF, Gorman JM (1993) Carbon dioxide hypersensivity hyperventilation and panic disorder.Am J Psychiatry 150: 1149-1157.[Crossref]

25. Wilhelm FH, Gerlach AL, Roth WT (2001) Slow recovery from voluntary hyperventilation in panic disorder. Psychosom Med 63: 638-649.[Crossref]

26. Ingvar DH, Bulow KB (1963) Respiratory regulation in sleep. Ann N Y Acad Sci 109: 870-881.[Crossref]
27. Hoes MJ, Colla P, Folgering H (1980) Clomipramine treatment of hyperventilation syndrome. Pharmakopsychiatr Neuropsychopharmakol 13: 25-28.[Crossref]

28. Klein DF (1987) Anxiety reconceptualized. Gleaning from pharmacological dissection-early experience with imipramine and anxiety. Mod Probl Pharmacopsychiatry 22: 1-35.[Crossref]

29. Ellison GD (1975) Behavior and the balance between norepinephrine and serotonin Acta Neurobiol Exp (Wars) 35: 499-515.[Crossref]

30. Jouvet M (1972) The role of monoamines and acetylcholine-containing neurons in the regulation of the sleep-waking cycle. Ergeb Physiol 64: 166-307.[Crossref]

31. vanPraag HM (1980) Central monoamine metabolism in depressions. I. Serotonin and related compounds. Compr Psychiatry 21: 30-43.[Crossref]

32. Ebuehi OAT, Akinwande AI (1993) An indirect evaluation of the effect of materia and post weaning protein and tryptophan malnutrition on the central serotoninergic metabolism. J Hosp Medicne 5: 48-55.

33. Ebuehi OAT, Adenuga AO, Erinle OO (1999) Effect of caffeine and ethano consumption on the metabolism of 5-hydroxy tryptamine in rats. J Med \& Med Sci $1: 31-38$

34. Ebuehi AT, Akinwande AL, Famuyiwa OO, Uzodinma EO (2005) Effect of marijuana smoking on blood chemistry and serum biogenic amines concentrations in humans. Nig $J$ Health \& Biomed Sci 4: 20-24.

35. Ebuehi OAT, Ikanone CE, Balogun AA, Akinwande AI, Famuyiwa OO(2009) Effects of administration of sertraline, clozapine,amitriptyline and imipramine on brain serotonin, liver enzymes and blood chemistry of rabbit. Int J Biol Chem Sci 3:85-94.

36. Sheehan DV (1982) Current concepts in psychiatry. Panic attacks and phobias. N Engl $J$ Med 307: 156-158.[Crossref]

Copyright: (C2016 Varney VA. This is an open-access article distributed under the terms of the Creative Commons Attribution License, which permits unrestricted use, distribution, and reproduction in any medium, provided the original author and source are credited. 